International Journal of Engineering \& Technology, $7(4.38)(2018) 78-81$
International Journal of Engineering \& Technology
SPC
Website: www.sciencepubco.com/index.php/IJET
Research paper

\title{
Risk Management Based on Model of Competences when Introducing Innovative Information Technology
}

\author{
S.A. Bogatenkov ${ }^{1 *}$, V.A. Belevitin ${ }^{2}$, M.L. Khasanova ${ }^{2}$ \\ ${ }^{1}$ Information Technology in Economics Department, South Ural State University, Lenin Av., 76, Chelyabinsk, 454080, Russia \\ ${ }^{2}$ Department of Motor Transport, Information Technology and Method of Teaching Engineering Disciplines, South Ural State \\ Humanitarian Pedagogical University, Lenin Av., 69, Chelyabinsk, 454080, Russia \\ *Corresponding author E-mail: bogatenkov.s.a@mail.ru
}

\begin{abstract}
Economic expediency and attractiveness of life quality improving are accompanied by risks of increasing instability and possible collapse of the world system. Forecasts of the labour market change connected with automation of working places and mass unemployment cause concerns. The task of risk management in the personnel training system for introduction of new information technology is considered. The purpose of the research is development of the methodology based on the models of competences including requirements for safe application of information-measuring systems, as well as for an education level, work experience and permit-towork documents in new conditions. A complex of new mathematical models, methods and technologies providing safety of the process of information technology introduction owing to the systemic approach to risk minimization is taken as a basis of the methodology. Invariant models provide economic effectiveness of processes of designing the system of safety and planning of educational paths. Models of personal paths of development and classes of competences provide didactic safety. Decision-making methods provide information, psychological, social and economic safety of the process of information technology introduction. The methodology is realised when introducing distance learning technologies in educational organisations of Chelyabinsk and the Chelyabinsk region.
\end{abstract}

Key words: Information Technology, Risk Management, Modelling, Competences

\section{Introduction}

The fourth industrial revolution leads to significant changes allowing people to communicate with machines in cybernetic systems and global networks. Industry 4.0 allows collecting and analysing large volumes of data providing an opportunity to quickly, effectively and flexibly create goods of high quality with minimal expenditures [1]. The main goals that are laid in the programme of digital economy development in Russia until 2024 include: provision of quick access to the Internet for each Russian person, including residents of remote human settlements; replacement of university diplomas and work record cards with the development path, "smart cities" and even an automated system of making state decision [2].

Economic expediency and attractiveness of life quality improvement are accompanied by risks of instability increase and possible collapse of the world system. The damage as a result of new information technology application is commensurable with annual growth of gross domestic product. The size of the damage is by $70 \%$ related to a human factor [3]. Forecasts of the labour market change cause concerns: for over 20 years, $47 \%$ of working places of the modern world will be automated and millions of workers will become unemployed [4].

In the light of such situation, an acute necessity to modernize the basis of educational projects for personnel training for work with new information technology arises. At that, improvement of models, using the concept of competency in the field of application of information and communications technology (ICT competencies), is most fundamental.

ICT competency can be determined as:
1) a complex concept, which reflects the way of individual life activity and includes purposeful effective application of technical knowledge and abilities in real life (A.A. Kuznetsov and E.K. Henner [5]);

2) new literacy, which includes abilities of active independent processing of information by a person, application of principally new solutions in unforeseen situations using technological means (A.L. Semenov) [6].

I.V. Robert points out the following constituents of the concept of teacher's ICT competency [7]:

1) teaching a subject using ICT means;

2) informational interaction among participants of the teaching and educational process in computer networks;

3) expert assessment of training software products;

4) prevention of negative consequences of using ICT means in the educational process;

5) automation of educational process management.

Taking into account the peculiarities of professional and pedagogical education and research of scientists in this filed, ICT competency of the graduate of an educational organisation implies one's motivated wish, readiness and ability to use effectively possibilities of ICT in conditions of:

- level professional and pedagogical education and involvement in information and communication educational environment, differing by the presence of distance learning, electronic business, security threats;

- multidisciplinary and multifunctional pedagogical activity when training, nurturing and developing skilled working personnel and specialists in accordance with the educational programme specialization [8].

A prospect direction for designing the personnel training for working with new information technology is application of 
methods of network modelling, which is based on application of the model of a complex of interrelated works aimed at achievement of a certain goal [9]. But as practice shows, on the whole the result of positive project management is realised not more than by half of its possibilities. In the opinion of the experts of American Project Management Institute (PMI), irrecoverable losses of organisations due to low quality of the developed management projects make 109 mln US dollars per milliard US dollars [10]. Approximately the same situation is observed concerning execution of educational projects on personnel training for working with new information technology (IT). Solution of the problem related to personnel competency formation for working with IT is hindered due to absence of the systemic approach to models, methods and technologies providing personnel with training for working with IT in terms of integrated safety and security. To provide didactic safety of professional and pedagogical education, in particular, application of the ICT competences' classification is expedient [11]. To solve problems of integrated safety and security, first of all, it is necessary to observe the following terms. First, for each job position of workers of professional and pedagogical education, it is necessary to define sufficient information for safe introduction of information-measuring systems (IMS) including a set of requirements for the education level, work experience, ICT competency content of a graduate of an educational organisation of professional and pedagogical education and for required documents to gain a permit-to-work with IMS.

Second, it is necessary to take into account competences and interests of all participants of the process of introducing the safety system of professional and pedagogical educational organisation (SS PPEO) and to comply with requirements for continuity and integratedness of education, implying successive completion of all levels of education.

Third, to assure reliability of SS PPEO when introducing innovative IT, it is necessary to apply methods based on both models and work experience of employees of professional and pedagogical education.

Fourth, to provide economic effectiveness of processes connected with designing SS PPEO and planning of educational paths, it is expedient to apply invariant models obtained as a result of analysis and systematization of the experience of introduction of different kinds of IT in different organisations.

In the light of such approach, when developing methodology of risk management and introducing IT based on models of ICT competences on the basis of analysis and generalization of IT introduction experience in different educational organisations, for each job position of workers of SS PPEO the following has been formed:

1. An invariant model of sufficient information for safe IT introduction. The model includes a set of requirements for the education level, work experience, ICT competency and for required documents to permit employees (specialists) of SS PPEO to work with IT (Table 1). The first three columns of Table 1 are general for all kinds of IT, and the third and the fourth columns are defined at the stage of adaptation to a specific kind of IT taking into account traditions of educational organisations.

Table 1: Invariant models of specialists' competences

\begin{tabular}{|l|l|l|l|l|}
\hline $\begin{array}{l}\text { № of } \\
\text { items }\end{array}$ & Education & $\begin{array}{l}\text { Work } \\
\text { experience, } \\
\text { mon. }\end{array}$ & $\begin{array}{l}\text { Document } \\
\text { for permit- } \\
\text { to-work with } \\
\text { IT }\end{array}$ & $\begin{array}{l}\text { Competency } \\
\text { for safe IT } \\
\text { application }\end{array}$ \\
\hline 1 & $\begin{array}{l}\text { Secondary or } \\
\text { secondary } \\
\text { vocational }\end{array}$ & 3 & Document 1 & Competency 1 \\
\hline 2 & $\begin{array}{l}\text { Secondary or } \\
\text { secondary } \\
\text { vocational }\end{array}$ & 6 & Document 2 & Competency 2 \\
\hline 3 & $\begin{array}{l}\text { Secondary or } \\
\text { secondary }\end{array}$ & 12 & Document 3 & Competency 3 \\
\hline
\end{tabular}

\begin{tabular}{|c|c|c|c|c|}
\hline & vocational & & & \\
\hline 4 & $\begin{array}{l}\text { Bachelor's } \\
\text { Degree course } \\
\text { or Specialist's } \\
\text { Degree }\end{array}$ & 3 & Document 4 & Competency 4 \\
\hline 5 & $\begin{array}{l}\text { Bachelor's } \\
\text { Degree course } \\
\text { or Specialist's } \\
\text { Degree }\end{array}$ & 24 & Document 5 & Competency 5 \\
\hline 6 & $\begin{array}{l}\text { Master's } \\
\text { Degree course }\end{array}$ & 3 & Document 6 & Competency 6 \\
\hline 7 & $\begin{array}{l}\text { Master's } \\
\text { Degree course }\end{array}$ & 36 & Document 7 & Competency 7 \\
\hline 8 & $\begin{array}{l}\text { Post-graduate } \\
\text { course }\end{array}$ & 3 & Document 8 & Competency 8 \\
\hline
\end{tabular}

2. An invariant model of the competency content for safe IT introduction. The model includes competences for effective application of IT, risks and methods for their minimization, based on both models and work experience (Table 2). The content of Table 2 is specified at the stage of adaptation to a specific kind of IT taking into account traditions of enterprises and organisations.

To provide the systemic approach to safe IT introduction, measures on fulfilling requirements for continuity and integratedness of education, implying successive completion of all levels of education starting from the general and ending with personnel training of top-qualification (post-graduate course), were taken. In accordance with the systemic approach, the process of personnel training for working with new IT is modelled by a hypergraph representing a generalization of the graph, in which each edge can connect not only two nodes, but also any subsets of nodes.

Table 2: An invariant model of the competencies' content of SS PPEO employees for safe IT introduction

\begin{tabular}{|c|c|c|c|c|}
\hline $\begin{array}{l}\text { № of } \\
\text { items }\end{array}$ & $\begin{array}{l}\text { IT } \\
\text { application }\end{array}$ & Risks & $\begin{array}{l}\text { Methods } \\
\text { based on } \\
\text { work } \\
\text { experience } \\
\end{array}$ & $\begin{array}{l}\text { Methods } \\
\text { based } \\
\text { models }\end{array}$ \\
\hline & \multirow[b]{2}{*}{$\begin{array}{l}\text { Electronic } \\
\text { document } \\
\text { circulation }\end{array}$} & \multirow{2}{*}{$\begin{array}{l}\text { Inadmissible } \\
\text { operation of } \\
\text { automation } \\
\text { devices }\end{array}$} & \multirow{2}{*}{$\begin{array}{l}\text { Transition to } \\
\text { traditional } \\
\text { document } \\
\text { circulation }\end{array}$} & \multirow{2}{*}{$\begin{array}{l}\text { Document } \\
\text { circulation } \\
\text { based on } \\
\text { models }\end{array}$} \\
\hline 2 & & & & \\
\hline 3 & \multirow[t]{2}{*}{$\begin{array}{l}\text { Solution of } \\
\text { tasks of } \\
\text { professional } \\
\text { activity }\end{array}$} & \multirow[t]{2}{*}{$\begin{array}{l}\text { Inadmissible } \\
\text { operation of } \\
\text { automation } \\
\text { devices }\end{array}$} & \multirow[t]{2}{*}{$\begin{array}{l}\text { Transition to } \\
\text { traditional } \\
\text { problem- } \\
\text { solving }\end{array}$} & \multirow[t]{2}{*}{$\begin{array}{l}\text { Problem- } \\
\text { solving based } \\
\text { on models }\end{array}$} \\
\hline 4 & & & & \\
\hline 5 & \multirow{2}{*}{$\begin{array}{l}\text { Organisation } \\
\text { of effective } \\
\text { operation of } \\
\text { automation } \\
\text { devices and } \\
\text { training } \\
\text { personnel for } \\
\text { working with } \\
\text { IT }\end{array}$} & \multirow{2}{*}{$\begin{array}{l}\text { Absence of } \\
\text { personal } \\
\text { development } \\
\text { paths and } \\
\text { inadmissible } \\
\text { operation of } \\
\text { automation } \\
\text { devices }\end{array}$} & \multirow{2}{*}{$\begin{array}{l}\text { Organisation } \\
\text { of } \\
\text { operational } \\
\text { control over } \\
\text { the operation } \\
\text { of } \\
\text { automation } \\
\text { devices }\end{array}$} & \multirow{2}{*}{$\begin{array}{l}\text { Planning of } \\
\text { personal } \\
\text { development } \\
\text { paths based } \\
\text { on models of } \\
\text { competences }\end{array}$} \\
\hline 6 & & & & \\
\hline 7 & $\begin{array}{l}\text { Strategic } \\
\text { planning of } \\
\text { the IT } \\
\text { introduction } \\
\text { process }\end{array}$ & $\begin{array}{l}\text { Unreasonable } \\
\text { decision- } \\
\text { making for } \\
\text { the IT } \\
\text { introduction } \\
\text { process, } \\
\text { absence of } \\
\text { consideration } \\
\text { of } \\
\text { competences } \\
\text { of all } \\
\text { interested } \\
\text { parties }\end{array}$ & $\begin{array}{l}\text { Decision- } \\
\text { making for } \\
\text { provision of } \\
\text { economic } \\
\text { safety of the } \\
\text { IT } \\
\text { introduction } \\
\text { process }\end{array}$ & $\begin{array}{l}\text { Strategic } \\
\text { planning of } \\
\text { IT } \\
\text { introduction } \\
\text { based on } \\
\text { models of } \\
\text { competences } \\
\text { of all } \\
\text { interested } \\
\text { parties }\end{array}$ \\
\hline
\end{tabular}

From the mathematical viewpoint, the hypergraph represents a pair (X, E) (Figure 1), where $\mathrm{X}$ is the filled set of objects of some nature named as hypergraph nodes, and $\mathrm{E}$ is the family of filled (not obligatory different) subsets of set $\mathrm{X}$, named as edges of the hypergraph. The hypergraph that models the process of personnel training for working with new IT is presented in Figure 1. The 
nodes of graph Xi correspond to the i-th models of specialists' competences (see Table 1). Arches Ei unite models of competences of specialists, participating in training at a certain level: E1 - secondary or secondary vocational education; E2 Bachelor's Degree course or Specialist's Degree; E3 - Master's Degree course; E4 - post-graduate course.

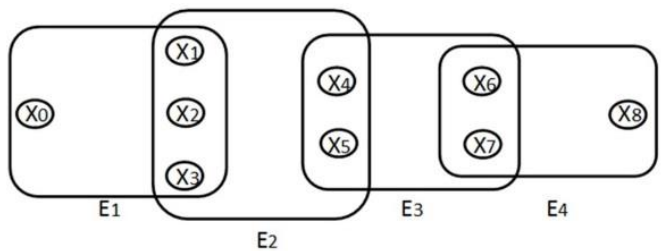

Fig. 1: Modelling of the systemic approach to personnel training using the hypergraph

The systemic approach to personnel training is provided by connectedness of the hypergraph since there is a path between each pair of arches of the hypergraph.

Thus, the models of specialists' competences were developed for introducing IMS taking into consideration the systemic approach to continuity and integratedness of education based on invariant models, minimizing economic risks as a result of reducing labour intensity of the development process. For each job position, sufficient information for safe introduction of IMS, including a number of requirements for the education level, work experience, the ICT competency content and necessary documents for permitto-work with IMS, was specified. To assure reliability of the system of safe IMS introduction, methods based on both models and work experience were applied.

Development of the risk management methodology when introducing IT, based on invariant models of sufficient information and the competency content for safe IT introduction, constituted a basis for designing of risk management methods based on competences' models.

To introduce new IT safely, the use of ICT competencies of interested parties is regulated as a compulsory condition, namely: competences for successful application of new IT, awareness of possible risks for professional activity safety and competences for realising methods, minimizing the influence of risks. Strategic planning of introduction of IMS based on the models of competences of interested parties includes adaptation of invariant content to a specific kind of IT and traditions of an educational organisation. In its turn, strategic planning of IMS introduction, based on the invariant IT model, provides economic efficiency of the designing process of the safety system for professional activity.

A guarantee of safe work with IT is implementation of necessary measures minimizing all existing risks with consideration of their degree of influence on SS PPEO. These requirements are determined by the necessity to consider all risks and interests of parties participating in the IT introduction process.

To determine the necessary set of measures providing SS PPEO, creation of the model of the composition of necessary measures is required. To take into account the interests of all participants of the new IT introduction process, it is necessary to form a model of assessment of measures' effectiveness. Requirements for creation and assessment of the personnel training system are met due to including representatives of all parties, participating in the IT development process, in the expert group.

Creation of the system of safe introduction of new IT in SS PPEO is possible only by means of formation of all requirements for competency of each specialist for safe IT application as a result of fulfilling the plan of educational paths; and planning of personal development paths based on models of competences is based on the procedure of selection of an effective education path from the set of their different variants differing by cost and time expenditures. In accordance with the requirement of the presence of diversity of variants, the process of personnel training for working with new IT is modelled by the graph, representing a pair $(\mathrm{X}, \mathrm{Y})$. Graph's nodes $\mathrm{Xi}$ correspond to the $\mathrm{i}$-th models of specialists' competences (see Table 1). Arches Yi unite models of competences of specialists of the same and neighbouring levels of training and show corresponding values of cost and time expenditures necessary for a transition to the next post. The graph, modelling a multivariant process of personnel training for working with new IT, is presented in Figure 2.

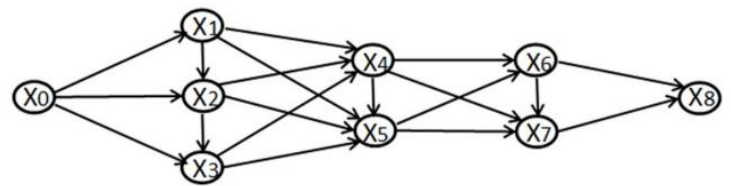

Fig. 2: Modelling of a set of variants of personnel training using the graph

A great number of variants of personal educational paths of development allow planning them in an optimisation approach by the criterion of minimization of time and cost. To solve these tasks, well-known methods of finding the shortest paths on the graph with preset values of arches are used. An important constituent of the model is consideration of the human factor, which is expressed in active influence of the manageable system on the process of managing SS PPEO. The aforesaid is evidence of the fact that the developed algorithm and the programme allow solving the task of network planning of personal educational paths of development by criteria of minimization of time and cost expenditures [18].

To provide economic security of the IT introduction process, the methods of decision-making of both technical and managerial nature are used. The methods of making technical decisions for providing safety of the IT introduction process include recommendations for application of IMS and distance learning technologies (DLT), as well as means of e-learning (EL).

First, the issues of provision of economic security of the IMS introduction process are related to the necessity of unification of different IMS databases. For example, the necessity of databases' unification is frequently conditioned by differences in information organisation by the manner of coding; by the structure of data files according to temporal characteristics (constantly or for over last 10 days, in particular). Because of these differences, the time and labour intensity of SS PPEO programmes' running increase significantly. To gain an economic benefit in this direction, a complex IMS with a unique organisation of measurable information is necessary.

Secondly, multimedia technologies for designing SS PPEO allow minimizing risks of economic and psychological nature. The technologies take into account the experience of creating multimedia training materials using templates and eidotechnical methods of information presentation.

Thirdly, Internet technologies for designing safe SS PPEO allow minimizing risks of economic and psychological nature. The technologies take into account the experience of creation of business game, automated systems of training and documental informational systems for specialists engaged in trade, as well as application of personal electronic diaries.

Methodology, methods of designing of safe SS PPEO in risk management based on models of competences when introducing innovative information technology are realised as applied to distant educational technologies and EL in educational organisations of Chelyabinsk and the Chelyabinsk region [17].

Scientific provisions and developments of safe SS PPEO designing in the practice of management and decision-making are laid out in 9 monographs, 7 textbooks and study guides, proceedings of 18 International conferences; they are protected by 24 author's certificates of electronic resources, registered in the joint fund of electronic resources "Science and Education". 


\section{Conclusion}

The task of risk management in the system of personnel training for IT introduction is solved. As a result of the research, the methodology based on the model of competences including requirements for safe IT application, as well as for the education level, work experience and documents for permit-to-work in new conditions, is developed. A set of new mathematical models, methods and technologies, providing safety of the IT introduction process due to the systemic approach to risk minimization, is assumed as a basis of the methodology:

1. Invariant models of sufficient information and content of competences for working with IT provide economic efficiency of the designing processes of the system of security and planning of educational paths. The models of personal development paths and classes of competences ensure didactic security.

2. Methods of risk management and decision-making ensure informational, psychological, social and economic security of the IT introduction process.

3. Methods of planning of personal paths of development and strategic IT introduction, intellectual support of managerial decision-making for the objective control over the personnel work and providing its security, as well as methods of making technical and managerial decisions, are applied during the introduction of DLT and EL at the South Ural State and South Ural State Humanitarian Pedagogical Universities and at the Azerbaijan Technical University [12 - 16].

\section{References}

[1] Bondar K (2017), What is in reality Industry 4.0? [Electronic resource]. http://innovacima.com/en/2017/11/09/what-is-industry4-0/

[2] Kruglov S, (2011). Umnye liudi, umnye goroda: chto nado znat o programme razvitiia tsifrovoi ekonomiki [Smart people, smart cities: what you need to know about the program of digital economy development]. http://tass.ru/ekonomika/4306382

[3] Tolmachev VD (2011), O kadrovom obespechenii sovremennoi energetiki, Energobezopasnost $i$ energosberezhenie [On staffing of modern power engineering, Energy security and energy saving], 1, 37-38.

[4] Hel I (2015), Industriia 4.0: Chto takoe chetvertaia promyshlennaia revolutsiia? [Industry 4.0: What is the fourth industrial revolution?] https://hi-news.ru/business-analitics/industriya-4-0-chto-takoechetvertaya-promyshlennaya-revolyuciya.html

[5] Kuznetsov AA, Henner EK (2010), Informatsionnye tekhnologii v obrazovanii [Information technologies in education], Obrazovanie Nauka, 7(75), 88-96.

[6] Zaitseva SA (2011), Metodicheskie osnovy formirovaniia IKTkompetentnosti budushchego uchitelia nachalnykh klassov [Methodical foundations of ICT competency formation of future primary school teacher], Vysshee Obrazovanie Segodnia, 4, 42-44.

[7] Robert IV (2008), Teoriia i metodika informatizatsii obrazovaniia (psikhologo-pedagogicheskie aspekty) [Theory and methodology of informatization of education (psychological, pedagogical and technological aspects)], 2nd ed., ext., IIO RAO, Moscow.

[8] Gnatyshina EA, Bogatenkov SA (2012), Poniatie informatsionnoi i kommunikativnoi kompetentnosti vypusknika uchrezhdeniia professionalno-pedagogicheskogo obrazovaniia [Concept of information and communication competency of graduate of vocational-pedagogical education institution], Vektor Nauki Toliatinskogo Gosudarstvennogo Universiteta, 2, 10-12.

[9] Gelrud, IJD, Loginovskii OV (2015), Upravlenie proektami: metody, modeli, sistemy: monografiia [Project management: methods, models, systems: monograph], Publishing Center of IUUrGU, Cheliabinsk.

[10] Pozniakov VV (2012), Upravlenie proektami dlya top-managerov [Project management foe top managers], Upravlenie proektami programmami [Project and Program Management], 3, 27-28.

[11] Bogatenkov SA (2013), Klassifikatsiia informatsionnykh i kommunikativnukh kompetentsii v professionalno- pedagogicheskom obrazovanii kak factor didakticheskoi bezopasnosti [Classification of information and communication competences in vocational professional education as a factor of didactic security], Mir Nauki, Kultury, Obrazovaniia, 1, 45-48.

[12] Bogatenkov SA, Gelrud IaD (2017), Decision-Making in the Application of Automated Information-Measuring Systems for Thermal Power Plants: The Experience of the Chelyabinsk Thermal Power Station-2, Bulletin of South Ural State University. Ser. Computer Technologies, Automatic Control, Radio Electronics, 17(1), 74-83.

[13] Bogatenkov SA, Malovechko SN, Kosterin VV (2016), Secure state power system models building. 2nd International Conference on Industrial Engineering, Applications and Manufacturing (ICIEAM), 1-5. DOI:10.1109/ICIEAM.2016.7911642.

[14] Bogatenkov SA (2017), Modeling of Safety System for Technical Diagnostics of Measuring Channels under Conditions of Information Introduction and Measuring Systems. 2nd International Ural Conference on Measurements (UralCon). IEEE, 323-329. DOI 10.1109/URALCON.2017.8120731.

[15] Bogatenkov SA, Gnatyshina EA, Belevitin VA (2017), Kompetentnostno orientirovannoe upravlenie podgotovkoi kadrov $v$ usloviiakh elektronnogo obucheniia [Competence-based management of personnel training under conditions of e-learning], Izd-vo Iuzhno-Uralskogo Gos. Gumanitarno-ped. un-ta, Cheliabinsk.

[16] Bogatenkov SA, Bogatenkov DS (2018), Metodologiia bezopasnogo vnedreniia informatsionnykh tekhnologii v sotsialnoekonomicheskoi sisteme professionalnoi deiatelnosti [Methodology of safe introduction of information technologies in the social and economic system of professional activity] Zhurnal Upravlenie Investitsiiami i Innovatsiiami, 1, 17-29.

[17] Belevitin VA, Gnatyshina EA, Chernovol IG (2017), Nauchoissledovatelskaia rabota magistranta: teoriia i praktika organizatsii i provedeniai: uchebno-metodicheskoe posobie [Academic research work of postgraduate: theory and practice of organization and conducting: study guide], Izd-vo Iuzhno-Uralskogo Gos. Gumanitarno-ped. un-ta, Cheliabinsk.

[18] Belevitin VA, Gafarova EA, Korchemkina IuV (2017), Vliianie ternarnosti predstavleniia uchebnoi informatsii na povyshenie kreativnosti obuchaiushchikhsia [Influence of ternary timing of presenting educational information on improving the creativity of students], European Social Science Journal (Evropeiskii Zhurnal Sotsialnykh Nauk), 6, 194-200. 